DE DE GRUYTER

OPEN

DOI: 10.1515/jolace-2016-0035

\title{
Marketing masculinity, branding the book: Current gender trends in the presentation of selected boys' adventure novels
}

\author{
Janice Robertson, University of South Africa, South Africa \\ janice@jrobertson.co.za
}

\begin{abstract}
Chris Bradford's Young Samurai series, and his more recent Bodyguard Series draw on a strong sense of hegemonic masculinity to secure popularity for the protagonist. The success of these books is particularly interesting when one considers the gender agendas that are embraced by modern western society and the extent to which general opinion has altered in terms of the performance of masculinity.

According to John Stephens in Ways of Being Male: Representing Masculinities in Children's Literature and Film (2002, p.x), a problem for boys, both in narrative fictions and in the world, is that hegemonic masculinity 'appears simultaneously to propose a schema for behaviour and to insist on their subordination as children, to conflate agency with hegemonic masculinity, and to disclose that, for them, such agency is illusory. These paradoxes are currently being increasingly dealt with as a theme in children's literature and film'. My paper will discuss these apparent paradoxes in Chris Bradford's novels in the context of a $21^{\text {st }}$ century child readership.
\end{abstract}

Key words: Children's literature, gender literacy, masculinity studies, adventure novel

\section{Background}

The school theatre was packed to capacity at the English boys' prep school in Pretoria, South Africa. For the past week, the boys had been eagerly anticipating the publicity talk by the widely published British author, Chris Bradford. Already loved by many of the boys as the creator of the Young Samurai novels, Bradford had come to South Africa for the launch of the third book in his new adrenalin stoked Bodyguard series. To start off the proceedings, two rather nervous looking schoolboys joined the author on stage and began to read out a welcome and introductory speech. Bradford had dressed in uniform black for the occasion and wore fashionable shades despite being indoors. The young boys stuttered their way through their lines, reciting Bradford's achievements as an author and musician. Suddenly, the hall was filled with the deafening sound of gunshots and Bradford, immediately embracing the persona of a bodyguard, shielded the two 
boys from the imaginary shots and shepherded them into the wings of the stage. The audience was thrilled, entranced.

The rest of the publicity stunt continued along similar lines, usually involving volunteers from the crowd to demonstrate evasion, surveillance and close combat techniques. Even the usual 'reading' from one of his books took the form of a thrilling dramatic skit with the boys who volunteered to act receiving free promotional posters and bodyguard accreditation sticker badges. The display was convincing as this is one of the characteristics that set Bradford apart as an author: before he wrote the Young Samurai series, he attained his black belt in Zen Kyu Shin Taijutsu. Recently, in preparation for his Bodyguard series, he had trained as a close protection officer: a qualified professional bodyguard with an intimate working knowledge of the lingo, strategies and techniques used in the field.

The boys found Bradford's approach irresistible. By the end of the talk, the entire body of students divided into three groups: the first for boys who had brought money to buy books after the show, the second for boys who were lining up to order copies of the books, and the third for the fans who had brought their well-worn copies of Bradford's books to school for him to sign. The marketing strategy had proved overwhelmingly successful. As I leaned back in my seat in the gallery, I considered the possibility that what these boys were so eager to possess was not just a bundle of cracking good stories. The other commodity, the deeper attraction lay, perhaps, in the display of capable, skilled and confident masculinity, the enactment of a persona that takes danger, risk and pressure in its stride. As a children's literature scholar with a masculinities research profile, my interest was piqued.

\section{Introduction}

Chris Bradford's bestselling books have been published in over 20 languages and have received several children's book award nominations. His hugely popular Young Samurai series tells the tale of Jack Fletcher, a twelve year old English boy with straw-blonde hair and azure-blue eyes, who is stranded and orphaned in Japan in the year 1611. By good fortune, he is adopted by a noble samurai Masamoto who allows him to train as a samurai warrior. The ninth instalment in this series is due for publication later this year.

The Bodyguard series, Bradford's most recent set of publications, is set in the general present and will be the focus of this paper. In reading order, Bodyguard: Hostage, Bodyguard: Ransom and Bodyguard: Ambush follow the adventures of Connor Reeves, a British teenager, who is recruited by Buddyguard - 'a secret close-protection organisation that differs from all other security outfits by supplying and training only young bodyguards' (frontispiece Bradford, 2014). The clientele is the growing class of young 'starlets', as well as the children of 
prominent politicians and billionaires. 'The best bodyguard is the one nobody notices' and that is why, the managers of this organisation claim, highly skilled Buddyguards are more effective than the typical adult bodyguard, 'who can easily draw unwanted attention. Operating invisibly as a child's constant companion, a Buddyguard provides the greatest possible protection for any high-profile or vulnerable young person' (frontispiece, Bradford, 2014).

One would ask, however, what would cause a young boy to put aside his international kickboxing ambitions and place himself, literally, in the line of fire. The reason is rooted in chivalric intentions: Connor's father died in service to his country eight years before and, as a fourteen year old, Connor is not in a position to provide for his aging grandmother and his mother who is suffering from multiple sclerosis. The Buddyguard organisation offers to pay for a professional nurse to live with Connor's maternal relations and provide all the medical care they may require. It is an irresistible offer for a boy who sees himself as the only possible provider in the household and he agrees to attend Buddyguard school in return for these benefits.

Connor is recruited by Buddyguard and earns his gold wings after his rookie mission to protect Alicia Mendez, the only daughter of the president of the United States. The novels are quick paced, with breathtakingly intense moments of crisis and suspense; yet, there are moments of reflection, even a hint of tenderness, which endear the protagonist to its audience.

\section{Young masculinity}

According to Capdevila (2010, p. 217), the heroes of recent adventure fiction aimed at adults 'are constructed with nostalgic reference to a past tradition of adventure and masculine ideals. They are virile, strong and valiant figures committed to action and the pursuit of a noble quest. They are furthermore endowed with the characteristics that make up 'peerless and magnificent manhood' (Green, 1993, p. 95): courage, sagacity, energy and 'musculinity,' which [...] signifies 'muscular physical power ... an expression of freedom and a form of protection, ... bodily invincibility' (Green, 1993, p. 133; Green referenced in Cadevila 2010, p. 217).

It is no coincidence, then, that we are introduced to our teenage hero in an undeniably masculine space: 'The fist caught Connor by surprise. A rocketing right hook that jarred his jaw. Stars burst before his eyes and he stumbled backwards. Only instinct saved him from getting floored by the left cross that followed. Blocking the punch with his forearm, Connor countered with a kick to the ribs' (Bradford, 2013, p. 11). Aged 14, Connor Reeves holds the UK title for the Under Sixteens Battle of Britain Kickboxing tournament with 8 years of martial arts training under his belt and the physique to prove it. 
From the start, it is obvious that the protagonist embodies the ideals of what gender researchers call 'hegemonic masculinity'. For the purposes of this paper, 'hegemonic masculinity' will refer to 'the configuration of gender practice which embodies the currently accepted answer to the problem of the legitimacy of patriarchy, which guarantees (or is taken to guarantee) the dominant position of men and the subordination of women' (Connell, 2005, p. 77). Robinson (2015, p. 61) notes that historically, there has been a move to recognising 'hegemonic masculinities', and asking how 'particular groups of men inhabit positions of power and wealth and how they legitimate and reproduce the social relationships that generate their dominance' (Brod, 1987, p. 92 in Robinson 2015, p. 61). From the outset, it would appear that Connor's performance of masculinity conforms to the aggressive-protective kind that sets manly heroes apart and he seems well equipped for the daunting task he has set for himself. Moreover, as Swain (2005, p. 224) observes, 'sporting success [...] is a key signifier of successful masculinity' and here, at least, Connor's ability appears unparalleled.

Morgan (in Murphy, 1994, n. p.), in his praise for the book Fictions of Masculinity claims that 'we are just beginning to understand masculinity as a 'fiction' or a localizable, historical, and therefore unstable construct'. Essentially, the notion that gender is not inevitable but constructed and performed has become the basis of research that analyses the way people interpret their identity and reenact gendered performances in the context of societal expectations. In masculinity studies, these performances may be seen as an indication of the type of masculinity a subject subscribes (or, more often, aspires) to. Connell (in Swain, 2005 , p. 224) summarises the concept by claiming that 'masculinity does not exist as an ontological given but comes into existence as people act'.

Gender performances that align with traditionally hegemonic male behaviour situate the subject in the general playing field with the consequence that successful re-enactment usually results in increased physical currency and acceptance, while failure may (and often does) lead to marginalisation. The successful performance of dominant masculinity is thus critical for those men and boys who wish to reap the benefits of the hegemonic domain, for those who seek acceptance and validation as a man amongst men.

Owing to the fact that 'the social and material practices through which, and by which, boys' masculine identities are defined are generally described in terms of what boys do with or to their bodies', several researchers have 'embraced the concept of embodiment' (Swain, 2005, p. 224). Connor's relationship with and control over his body is central to his identity and capability as a bodyguard and all the years of martial arts training pay off in situations when he is required to perform at an almost impossibly high level of precision with instinctive speed. The following passage, for example, shows Connor in action as he attempts to protect the US president's daughter, Alicia (who is not yet aware of Connor's status as 
personal protector), from two muggers: "Gold Tooth snatched for his prize. Connor instinctively stepped in to protect Alicia. [...] The situation demanded an all-ornothing approach and he drove the edge of his hand into Gold Tooth's throat. [...] Connor immediately followed up with a hook punch to the solar plexus, then a lightning-fast upper cut to the jaw. There was a bone-jarring crunch and the gangster's gold tooth flew from his mouth. Over in less than five seconds, the final punch knocked the former Gold Tooth unconscious and he collapsed to the sidewalk in a heap" (Bradford, 2013, p. 229-230).

And the heroics are not yet over! No sooner has Connor disposed of this threat than he is stabbed in the side by Gold Tooth's accomplice. The reader is aware, by now, that Connor has developed the habit of wearing stab-resistant T-shirts (supplied by Buddyguard to its recruits), a circumstance which makes Connor's survival plausible (to a certain extent, that is). In this first real attempt upon his life and that of his Principal (the person he is assigned to protect), Connor "felt a sharp stab of pain in his ribs as the blade hit its mark. But the adrenalin blocked out the rest of the damage. Battling now for his own survival as well as Alicia's, Connor fought with the fury of a tiger. He palm-striked Crew Cut in the face, stunning and weakening his opponent. Then, grabbing the gang member's hand that held the knife, he spun himself under Crew Cut's arm. The whole series of joints from wrist to shoulder twisted against themselves. The effect was instantly crippling. [...] Connor then finished off the gang member with a strike to a pressure point at the back of his skull. Crew Cut ceased screaming and crumpled to the ground.

Ensuring that there were no other immediate threats, Connor pulled Alicia to her feet.

'Are you hurt?' he asked." (Bradford, 2013, p. 231).

If this had been a James Bond movie, this would have marked the moment when the main female character falls hopelessly and distractedly in love with the hero. And yes, this is exactly what happens to Alicia. After witnessing Connor's selfless and flawless performance, she begins to consider him in a romantic light and the narrative gains interest on an emotional level. Connor is caught in a moral dilemma. Upon entering his duties as a bodyguard, Connor had sworn, under oath, not to become 'involved with' (Bradford, 2013, p. 255) his Principals. Yet he is deeply attracted to Alicia. Part of the 'action' now involves a physical and emotional balancing act in which Connor must remain close enough to Alicia to allow him to fulfil his mission as her protector, and yet not go against his commitment to the professional code of conduct.

While this provides impetus and dynamics for the narrative, the episode presents another underlying message: the successful performance of masculinity puts one in line to receive the recognition and benefits of hegemony; a prize which 
Connor undoubtedly, and the young male reader, potentially, seeks. Connor seems to not only embody, but epitomise the 'muscular physical power ... an expression of freedom and a form of protection, ... bodily invincibility' that Green (1993, p. 133; Green referenced in Cadevila, 2010, p. 217) refers to in his book, The Adventurous Male: Chapters in the History of the White Male Mind.

Picking upon Green's apt term, it is, moreover, Connor's 'musculinity' that gives him the dominant position in this extract. Notably, he reaches down to lift Alicia to her feet after defeating the attackers; his bearing confident and controlling. By contrast, Alicia is depicted as frozen with fear at the start of the fight and she eventually succumbs to 'brain fade' (Bradford, 2013, p. 229), a temporary, yet natural reaction to unexpected danger which bodyguards are trained to avoid. In effect, there are three potential dangers in the episode above: two strong assailants and one terrified Principal whose reactions could jeopardise the success of the protagonist's efforts.

While it may seem that Bradford is presenting a rather helpless image of femininity here - the typical (and often warranted) catalyst for reactionary feminist commentary - it must be admitted that this implied incompetence does not necessarily characterise all the girls and women in Bradford's books. In fact, one his female Principals, the teenage daughter of a French ambassador to Central Africa, saves Connor from a black mamba and later joins him in fighting a particularly strong poacher who is attempting to hold them hostage: "In the second that Connor took to consider his next best target, Amber stepped up and kicked Muscleman straight between the legs. The poacher's eyes bulged and he bent double, expelling a pained gasp. Then she hammer-fisted him in the temple. Muscleman went down like a felled buffalo. Connor stared at Amber in stunned admiration." (Bradford, 2015, p. 279).

It is refreshing to see a girl character who is actively involved in protecting herself and her (momentarily stunned) protector. There is certainly no evidence of 'brain fade' in Amber's reaction to danger here, with both bodyguard and Principal working with the common goal of survival in view.

Another notoriously feisty female character is one of his fellow bodyguards, a girl called Ling, who fights every bit as hard as Connor despite the fact that she has not yet earned her Buddyguard wings. We are told that although Connor 'was a black belt in jujitsu and kickboxing, that didn't mean he took a match with Ling lightly. At their very first encounter, she'd demonstrated she was a supremely tough combatant. In Amir's words, "Ling always wins her fights"' (Bradford, 2014, p. 45). Connor respects Ling's skill and, upon her request, does not hold back in his attack in deference of her gender. In one particular instance, Ling challenges Connor to a knockout to chastise him for a comment which she deems to be sexist. In the kickboxing ring, she channels her frustration into her fight moves: 
Like a whirling dervish, Ling came at him with a flurry of kicks and punches. Connor fought hard to defend himself. He ducked her spinning back fist, blocked her cross and evaded her crescent kick. As he retreated from Ling's relentless onslaught, Luciana goaded him from the ringside, "Some champion you are, Connor!"

Needled by the taunt and wanting to get a word in edgeways with Ling, Connor now went on the attack.

"Ling, I meant you got the job," he replied with a blistering combination of jab, cross and upper cut, "because ... our two Principals ... are girls. It therefore makes sense -" he almost floored Ling with a back fist - "to have a female bodyguard. [...] You can go places I can't. [...] And their protection is supposed to be low profile, so a girl bodyguard will be even less noticeable than a boy."

Connor grunted as Ling thrust a front-kick into his gut, forcing him backwards.

"Is that low profile enough for you?" grinned Ling, relishing the buzz of the fight.

Although this extract demonstrates Ling's physical and mental strength, it also highlights the fact that, in order to gain the dominance, acceptance and respect she craves in this traditionally masculine space, she must perform and excel in the activities which define its hierarchy.

According to Reardon and Govender (2011, p. 79), 'the male body has come to symbolize masculine characteristics such as power, control and invincibility. [...] Not only the body's size and shape, but also the skills and movements it is capable of all constitute ways in which masculinity is performed through the male body.' They further claim that 'the use of the body in aggressive and intimidating ways within peer relationships is a key means through which adolescent boys define and affirm their masculinity' (Reardon \& Govender, 2011, p. 79). Apart from the 'musculinity' required on the field during a mission, the dynamics between the male bodyguards training at Buddyguard school also give rise to intense displays of aggression to prove status and gain validation. In this sphere, Connor's main competition is Jason, a young Australian boxer who takes it on himself to make sure that the newbie kickboxing champion doesn't get too high an opinion of himself. Although their 'friendly' sparring and training sessions sometimes flare up into actual fights, they generally maintain a decent façade for the sake of (the aptly named) Alpha Team they both support in a professional capacity. Connor, however, recognises Jason's antagonism as a bid to maintain his position in the school. He reflects that 'although their relationship was still fractious, Connor had come to realise Jason wasn't a bad lad in himself. Just neither of them wanted to be second best' (Bradford, 2014, p. 101).

Nevertheless, as Swain (2005, p. 215) notes, 'schools are invariably hierarchical and create and sustain relations of domination and subordination; each orders certain practices in terms of power and prestige as it defines its own distinct gender regime" (2005, p. 215). Inevitably, then, in this school, perhaps more so 
than in any other, the boys are "consciously concerned about the maintenance of their bodies; they can be seen learning to control their bodies, acquiring and mastering a number of techniques [...]; and they can be seen using them in the appropriate ways that being a boy demands. Moreover, they are aware of the body's significance, both as a personal (but unfinished) resource and as a social symbol, which communicates signs and messages about their self identity". (Swain, 2005, p. 224).

Even in this arena, where young boys have been handpicked on the grounds of their suitability as bodyguards there are the (arguably oversexed) topdogs, the less assertive underdogs and the middling class of boys who recognise the unstated hierarchy. As Connell observes, 'in every setting [...] there will be a hierarchy of masculinities, and each will generally have its own dominant, or hegemonic, form of masculinity, which gains ascendance over and above others; it becomes "culturally exalted"' (Connell in Swain, 2005, p. 220).

When, after the success of his rookie mission, Connor is awarded his gold wings, he immediately becomes the target of renewed attempts by the other boys to reaffirm their own positions despite their officially subordinate status. The situation merely plays in Connor's favour, however, as he, in turn, is challenged to 'up his game' even more and hone his skills in order to save face; the rivalry serves as an unofficial aspect of the curriculum at this unique school that serves to toughen the recruits for the more malicious threats that await on assignments. Connor, as a winner in the game of masculinity hierarchy, understands the rules and dedicates himself with renewed energy to his training, pushing his body to, at times, seemingly insane limits. According to Swain (2005, p. 224), this is typical of the workings of the hegemonic domain where 'for much of the time, boys define their masculinity through action, and, [...] the most esteemed and prevalent resources that boys draw on to establish status are physicality and athleticism, which are inextricably linked to the body in the form of strength, toughness, power, skill, fitness and speed".

This observation supports the concept of embodiment mentioned earlier, in which 'the social and material practices through which, and by which, boys' masculine identities are defined' (Swain, 2005, p. 224) position boys as 'embodied social agents, for they do not merely have a passive body that is inscribed and acted upon; they are actively involved in the development of their bodies throughout their school life' (Swain, 2005, p. 224). Moreover, as Connell (1995) suggests, bodies are both the 'objects and agents of practice, with the practice itself forming the structures within which bodies are appropriated and defined' (in Swain, 2005, p. 224). For example, in Connor's world of close combat and high profile protection, the physical demands on masculinity are necessarily high, yet it is these very expectations and the means employed to meet them that produce both the object and the practice of this construction. More importantly for the concept of 
embodiment, Connor is an active participant in his development, an agent in control of his own body and its actions. After all, as Whitehead and Barrett (2001, p. 17) observe, 'masculine power' is largely exercised through self-regulation and self-discipline - a process of 'identity work".

For Connor, however, the attainment of 'strength, toughness, power, skill, fitness and speed' (Swain, 2005, p. 224) is not merely a matter of status; it is a means of survival. These are necessary skills in his profession, ones that could mean the difference between life and death. 'Featherstone (1982, p. 18) asserts that our inner and outer bodies are, in fact, 'conjoined' in consumer culture, with the aim of inner body maintenance being the improvement of outer body appearance and the cultivation of 'a more marketable self'. Thus bodies now have an important exchange value' (McKay et al., 2005, p. 280).

Featherstone's observations take on a rather ominous light in the context of the boy bodyguard. He is training his body, fine-tuning his reflexes to become a better bodyguard - more marketable, in a sense - a body whose services can not only be bought but who is expected to place himself as the final shield, the last point of defence for the significant and vulnerable Principal. The body that he has trained to execute actions with flawless precision can, in fact, be read as a marketable commodity for the comfort and safety of illustrious clients.

In his profession as a bodyguard, Connor's body actually takes on a physical 'exchange value', and is potentially expendable. In extreme cases, for example, the bodyguards are trained to provide body cover to their Principals; in effect, to place themselves between the client and the threat. Over the course of the three novels, Connor frequently does this, the first serious episode of this kind being when he takes two bullets for Alicia in an assassination attempt. Having sensed and identified the threat just seconds before the attack, Connor launches Alicia out of harm's way and is shot in the chest and the leg. His bullet proof shirt prevents a fatal upper body wound but he takes some time to recover from the flesh wound in his thigh. It's all part of the job, it seems, and Connor is dubbed 'Bullet-catcher' (Bradford, 2013, p. 414) in his get well card from Alpha Team at headquarters. Earlier in the novel, Connor deliberates about the potential consequences of becoming a Bullet-catcher (as some bodyguards are indeed called) and he wonders whether this is a risk he is willing to take and whether he would even 'have the guts to throw himself in the line of fire' (Bradford, 2013, p. 102).

After proving to himself and others that he is indeed capable of such an act, Connor suffers from the trauma of the experience, reliving the shooting in grotesque nightmares; even then, however, his main fear seems to be that he could so easily have been too late to protect his Principal. The fear of failure to perform his duty seems to outweigh his fear of personal injury. He has become, in fact, an ideal military recruit. But this is material for another research paper. 


\section{Conclusion}

In an article entitled 'He comes back badder and bigger than ever!', Capdevila (2010, p. 217) claims that adventure novels allow heroes 'to stand tall among lesser men and to stake out the space of action and adventure as their own manly turf'. She relates Neal King's comment that it is in the realm of adventure that the hero 'can throw his head back and howl while knives skewer thighs, fists pound faces, and bullets rip flesh. [Heroes] call this manly turf their own. They earn it by killing criminals and playing to live another day' (King, 1999, p. 201). Connor Reeves performs his masculine role in this harsh environment with flair. Whether battling pirates in the Seychelles or wrestling a crocodile in Central Africa, the hero stakes his life on the belief instilled in him by his father that the strong should protect the weak. Like the late nineteenth-century adventure tradition which was, in Richard Phillips' words, thoroughly 'committed to the continuous reinscription of dominant ideologies of masculinity' (1997, p. 5; in Capdevila, 2010, p. 216), the Bodyguard series validates the manly hero's ability and therefore, his right, to assume physical and political ascendance over all other gender configurations.

It would appear, moreover, that Chris Bradford has harnessed the marketability of hegemonic masculinity and capitalised on a (perhaps initially latent) desire in $21^{\text {st }}$ century young male readers to experience, albeit in a surrogate capacity, the thrill of the masculinity game and the triumph of invincible 'muscularity' over every form of opposition. The popularity of the series is significant in the light of current social and political agendas of gender activists that seek to destabilise the masculinity hierarchy. In many cases, these awareness campaigns have made considerable progress in shaping new, less exclusive, expectations for gendered performances. But for many young Bodyguard fans across the globe, Connor is still king.

\section{References}

Bradford, C. (2013). Bodyguard: Hostage. Penguin: London.

Bradford, C. (2014). Bodyguard: Ransom. Penguin: London.

Bradford, C. (2015). Bodyguard: Ambush. Penguin: London.

Capdevila, I. S. R. (2010). 'He comes back badder and bigger than ever!' Readapting the masculine and negotiating the feminine in treasure hunting adventure fiction. Journal of Gender Studies, 12(3), 215-228.

Green, M. (1993), The Adventurous Male: chapters in the history of the white male mind. Pennsylvania University Press: Philadelphia.

Kimmel, M. S., Hearn, J. \& Connell, R. W. (eds) (2005), Handbook of Studies on Men and Masculinities. Sage: London.

King, N. (1999), Heroes in Hard Times: Cop Action Movies in the U.S. Temple University Press: Philadelphia. 
McKay, J., Mikosza, J. \& Hutchins, B. (2005). "Gentlemen, the lunchbox has landed": Representations of Masculinities and Men's Bodies in the Popular Media. In Kimmel, M. S., Hearn, J. \& Connell, R. . (Eds.), Handbook of Studies on Men and Masculinities. Sage: London.

Murphy, P.F. (1994), Fictions of Masculinity: Crossing Cultures, Crossing Sexualities. NYU Press: New York.

Reardon, C. A. \& Govender, K. (2011) "Shaping up": The relationship between traditional masculinity, conflict resolution and body image among adolescent boys in South Africa. Vulnerable Children and Youth Studies, 6(1), 78-87.

Robinson, V. (2015). Masculinity Studies, Gender Relations and Feminism. In Introducing Gender and Women's Studies. Palgrave: London.

Swain, J. (2005). Masculinities in Education. In Kimmel, M. S., Hearn, J. \& Connell, R. . (Eds.), Handbook of Studies on Men and Masculinities. Sage: London.

Whitehead, S. \& Barrett, F. J. (2001). The Masculinities Reader. Polity Press: Cambridge.

\section{Contact}

Dr Janice Robertson

PO Box 299

Midstream Estate 1692 SouthAfrica janice@jrobertson.co.za 